El estudio del arte rupestre en Venezuela, door Jeannine Sujo Volsky. Universidad Católica 'Andrés Bello', Centro de Lenguas Indígenas, Caracas, 1975, $228 \mathrm{blz}$

De toevoeging 'en Venezuela' in de titel van dit belangrijke werk zou kunnen misleiden: de historie van het onderzoek van rotskunst en de kritische bespreking van de literatuur hierover beperken zich inderdaad tot Venezuela. Maar het hoofdbestanddeel van dit boek: een (voorgestelde) methodologie van de studie van rotsinscripties (petroglyphen) en rotsschilderingen (petrographieën), is universeel en richt zich tot iedere archeoloog, anthropoloog of welke onderzoeker dan ook die zich op dit terrein beweegt.

Het 'arte rupestre' (rotskunst) in de titel van Sujo's boek - waarmee inscripties en schilderingen bedoeld zijn - lijkt mij te ruim genomen. Het beeldhouwwerk aan rotsen valt namelijk eveneens onder deze benaming.

Zuidamerikaanse rotsinscripties en rotsschilderingen, en ook die van de Antillen, vormen één groot raadsel voor de archeoloog. Onbekend is of niet vast staat: wie ze gemaakt hebben ('Indianen'?); wanneer ze gemaakt zijn; hoe ze vervaardigd zijn; met welk doel ze gemaakt zijn; wat ze voorstellen (àls ze iets 'voorstellen').

Wel staat nu vast: dat ze voor het overgrote deel precolombiaans zijn; dat het géén schrifttekens zijn, dus geen alfabetische of syllabische symbolen en ook geen pictogrammen (beeldschrift); dat de huidige Indianen geen enkel idee hebben over hun betekenis, oorsprong enz. Vanaf de zeventiende eeuw hebben onderzoekers daar naar geïnformeerd bij bewoners van gebieden waar rotskunst voorkomt.

Het is waarschijnlijk deze vaagheid die gemaakt heeft dat de literatuur wemelt van 'verklaringen', dikwijls de meest fantastische, gegeven vaak zonder een spoor van argumentatie, laat staan bewijs, door onderzoekers met een goede naam in de wetenschap. Dit maakt literatuuronderzoek op dit terrein tot een vermoeiende, ontmoedigende bezigheid. $\mathrm{Er}$ is een tweede reden waarom dit soort onderzoek vaak onnodig zwaar is: de geringe mate van exactheid en zorg. vuldigheid in de beschrijvingen en afbeeldingen, waarbij flagrante tegenspraken niet zeldzaam zijn. Generaliseringen mogen uit den boze zijn, er is echter moeilijk te ontkomen aan de indruk dat het in een artikel over petroglyphen niet zo nauw komt met de wetenschappelijkheid. Dit geldt onverminderd voor recente literatuur, al zijn er natuurlijk gunstige uitzonderingen.

De inventarisatie is uiteraard de basis voor een verantwoorde studie van het verschijnsel, ze is echter niet meer dan een basis. De tweede fase is: greep krijgen op de veelheid van materiaal, een typologie ontwerpen die operationeel is; kortom: komen tot een werkbare taxonomie. Slechts via betrouwbare inventarisatie en verhelderende systematisering van het materiaal komt men tot de derde fase in het onderzoek: interpretatie van het verschijnsel, samenhang met andere cultuuruitingen, datering, inpassing in het totale onderzoek van de prehistorie van Zuid-Amerika, enz.

En het is hier dat het werk van Jeannine Sujo 'in een behoefte voorziet', door haar voorstellen voor een methodiek van inventarisering en van ordening. 
El estudio del arte rupestre en Venezuela is een 'tesis de grado' om de titel van - Antropoloog te verkrijgen an de Universidad Central de Venezuela, gemaakt onder leiding van Dr. Alberta Zucchi, op aanwijzingen van de hoogleraren J.M. Cruxent, Mario Sanoja en Marshall Durbin. Het was vooral de bekende Venezolaanse archeoloog Cruxent, auteur o.a. van de bijdrage 'Archeologie' in de Encyclopedie van de Nederlandse Antillen (samen met Irving Rouse) die haar wees op de noodzaak, te komen tot een methodologie die het mogelijk zou maken, het materiaal te systematiseren.

De auteur had geen gebrek aan medewerking; in haar dankwoord worden niet minder dan vijftig personen genoemd.

Het werk bestaat uit drie delen. In het eerste wordt een uitgebreid chronologisch overzicht gegeven van het werk van onderzoekers die publiceerden over Venezolaanse rotskunst, gevolgd door een analyserende en critische bespreking van die werken. Dit gedeelte is ook van belang voor de petroglyphen- en rotsschilderingenstudie van Suriname en de Nederlandse Antillen, o.a. wegens de uitvoerige bespreking van de ideeën van Von Humboldt, de gebroeders Schomburgk, Im Thurn, Koch Grünberg en anderen.

In het tweede deel worden uitvoerige aanwijzingen gegeven voor een correcte inventarisatie, en wordt vervolgens een methode van indeling voorgesteld. Het derde deel geeft pogingen tot interpretatie en de conclusie uit het gehele werk.

Om enige indruk te krijgen van de rijke inhoud van dit boek volgt hier een opsomming van de hoofdstukken, waarvan de meeste nog uitvoerig zijn onderverdeeld.

Eerste deel. Onderzoekingen over petroglyphen: A. Chronologisch overzicht van de auteurs. B. Analyse en kritiek.

Tweede deel. Voorstel voor een methodologie: 1. Codificatie van het archief. 2. Regionale benaming. 3. Ontdekkers. 4. Geografische ligging. 5. Type vindplaats. 6. Geologische gesteldheid. 7. Staat van conservering. 8. Techniek van vervaardiging. 9. Techniek van reproductie. 10. Bewerkt oppervlak. 11. Rang schiking en identificatie. 12. Methodologische analyse. 13. Stijlzones. 14. Berekeningen (met behulp van de numerieke taxonomie). 15. Chronologie (relatieve en absolute).

Derde deel. A. Interpretatie van symbolische en sociologische gegevens. B. Conclusies. C. Bibliografie.

Slot: Illustraties. Inhoud.

De voorgestelde, uitvoerige en zeer specialistische werkwijze maakt een duidelijke scheiding tussen de mensen in het veld en degenen die de gegevens verwerken. De vaardigheden, activiteiten en mentaliteit van iemand die, zich conscientieus houdend aan de punten 1.10 van het tweede deel, rotsinscripties en schilderingen inventariseert, verschillen aanmerkelijk van die van de persoon in de studeerkamer die zich in de punten 11-15, gewapend met de kennis van moderne taxonomische technieken, over die gegevens buigt. Gevreesd moet worden dat de hier voorgestelde veldwerktechniek in de praktijk door zijn veeleisendheid en gecompliceerdheid niet uitvoerbaar zal blijken te zijn, tenzij in geval van een betrekkelijk kleine groep, gemakkelijk bereikbare tekeningen. De hele opzet riekt naar de studeerkamer. Nergens in het werk wordt vermeld of de methode van inventarisatie die voorgesteld wordt, al eens in de praktijk toegepast is.

Deze kritiek neemt niet weg, dat de noodzakelijkheid voor de tweede man, 
de verwerker en interpretator aan het thuisfront, om over dit soort gegevens te beschikken, aannemelijk lijkt. De hier beschreven inventarisatieprocedure heeft dus zijn nut als ideaal-methode, streefnorm voor de veldwerker; wel niet ten volle haalbaar in het veld, maar wel de activiteiten daar richtend en uitbreidend. Daarnaast is ze van belang voor de uitputtende beschrijving van een beperkte, toegankelijke groep materiaal, als basis voor een methodologische analyse. Tenslotte biedt ze een schat van practische aanwijzingen: mogelijkheden voor tweeen driedimensionale opname met behulp van allerlei technieken.

Een oordeel over de analyse- en interpretatiemethodes die in het werk aangeboden worden, is moeilijk. De stof is niet eenvoudig en het is niet mogelijk, een en ander 'even te proberen'. De presentatie wekt echter het vertrouwen, dat iemand die de gecompliceerde taxonomische technieken beheerst of die bereid is, zich die eigen te maken, zeker wel resultaten zal boeken. Het wachten is wederom op degene die het inderdaad eens gaat doen!

Slotsom: Een belangrijk, voornamelijk theoretisch georiënteerd werk, dat een leemte in het rotstekeningonderzoek opvult doordat het een duidelijke methodologische aanpak van dit werk voorstelt, maar dat zijn waarde uiteindelijk in de praktijk bewezen moet zien en dan waarschijnlijk nogal wat gewijzigd zal worden.

\section{C.N. Dubelaar}

Antilliaans Nederlands, door A.J. Vervoorn. Schakels NA 61, Uitgave Kabinet Ned.-Ant. Zaken, (1976), 71 blz.

De aanleiding tot het schrijven van bovengenoemd werkje was dat de auteur, neerlandicus aan de Technische Hogeschool te Eindhoven, te maken kreeg met aanpassingsmoeilijkheden en studieproblemen van Antilliaanse studenten aan de Hogeschool. Reeds eerder had hij met F.J. van Wel gewerkt aan een soortgelijke publicatie over Het Nederlands in Suriname (Schakels S 81).

Vanuit zijn ervaring stelt Vervoorn heel duidelijk, dat een van de belangrijkste redenen van de moeilijkheden voor de Antilliaanse studenten in Nederland gelegen is in de onzekerheid met betrekking tot het taalgebruik. De oorzaak hiervan ligt in de grenssituatie van het Nederlands op de Antillen zèlf. Hij zegt hierover: ' . . het is vooral de officiële taal en slechts voor een minderheid ook een levende taal. Deze grenspositie leidt enerzijds tot een grote gevoeligheid voor de ABN-norm in het onderwijs, hetgeen duidelijk negatief en kwellend werkt. Bij diverse auteurs vinden we daarvan de weerslag. Men vindt het Nederlands, of misschien meer nog het Nederlandse onderwijs, een vreemde zaak die zeker in emotionele situaties te kort schiet. Anderzijds heeft de grenspositie ook duidelijk invloed op het soort Nederlands dat gebruikt wordt' (blz. 7). Ik vermoed dat 'kwellend' een drukfout is en 'knellend' bedoeld was. Want dat is eigenlijk de strekking van Vervoorns betoog: geef een eigen Antilliaans Nederlands de ruimte om te groeien en houd niet zo krampachtig vast aan het ABN. Ik kan dit standpunt slechts toejuichen. Vervoorn neemt hierdoor een positie in tegenover bv. J.H. de Palm en een oudere auteur als J. van Ginneken. Hij verwijt deze laatste in zijn Handboek der Nederlandsche Taal, deel I, 1913, "een geborneerde Hollandse zelfverzekerdheid" tenopzichte van het taalge. bruik van Antilliaanse leerlingen van die tijd op het Nijmeegse Canisiuscollege en ten opzichte van de situatie van het Nederlands op de Antillen, met name op 
Aruba en Curaçao. Toch is de bewuste passage bij van Ginneken zeer interessant. Ze wijst immers op het vrijwel algemene gebruik van het Papiaments op die eilanden ook in de 'hogere' kringen; de Antilliaanse leerlingen zullen daar zeker in die tijd toe behoord hebben. Het toont aan dat ook voor de komst van de olieindustrie het Papiaments de normale omgangstaal was van vrijwel iedereen. Dit wordt nog eens bevestigd door een opmerking in de Encyclopaedie van Nederlandsch West-Indië, waar men anno 1915 onder het trefwoord 'Nederlandsch' (blz. 503) kan lezen: "Op de Nederl. W.-I. Eilanden is het Nederlandsch de officiële taal, de taal der ambtenaren. Op de hoofdplaats van Curacao kan elk beschaafd Curaçaonaar Hollandsch spreken, lezen en schrijven; toch wordt deze taal weinig gebruikt ... De omgangstaal van het volk en zelfs van de groote meerderheid der ontwikkelden is echter het Papiamentsch". En wat verderop de bijna profetische uitspraak: "Niettegenstaande het Hollandsche onderwijs op de scholen, is het niet te verwachten dat het Engelsch op de Bovenwindsche en het Papiamentsch op de Benedenwindsche eilanden verdrongen zullen worden". Dat was de situatie aan de vooravond van de komst van de olieindustrie en deze constatering staat tegenover de mening van sommigen dat pas nà de komst als reactie bv. op de groep van de Nederlanders het Papiaments als in-group kenmerk door allen van Curaçaose afkomstig gesproken zou worden. Het Papiaments had hierdoor ook al veel langer een algemene culturele sanctie gekregen waardoor het Nederlands nog meer in een 'grenspositie' was terecht gekomen. Als men van Papiaments moest gaan vertalen in het Nederlands betekende dat bovendien denken in een geheel ander cultuurpatroon.

Ondanks mijn waardering voor Vervoorns opstelling en werk, toch een paar kritische en aanvullende opmerkingen. Op blz. 16 vergelijkt de auteur de situatie volgens de opgave van Van Ginneken uit 1913 over percentages van het gebruik van de verschillende talen op Curaçao met gegevens van 1960. Niet helemaal duidelijk is de uitleg die hij geeft over de toename van het Engels op blz. 18. Hij meent dat dit te verklaren zou zijn doordat de Bovenwinden, die bij Van Ginneken niet meetelden, dat in 1960 'uiteraard' wel deden. Is zijn lijstje van 1960 dan van toepassing op de gehele Ned. Antillen of alleen op Curaçao? Of heeft zijn opmerking betrekking op de aanwezigheid van Bovenwinders op Curaçao? Die waren er in de tijd van Van Ginneken inderdaad practisch niet.

Vervoorn citeert meerdere malen met instemming Prick van Wely's Neerlands Taal in 't Verre Oosten van 1906 en hij komt tot de constatering: 'De toepasbaarheid van zijn uitspraken op het Antilliaans Nederlands is herhaaldelijk opvallend groot' (blz. 34). Hij sluit ook aan bij Prick van Wely als het gaat om de wenselijkheid van de samenstelling van een Indisch-Nederlands woordenboek en hij brengt dat over op het Antilliaans Nederlands. Ik vermoed en ik hoop dat Vervoorn daar zèlf aan werkt, maar waarom niet nù al vast wat meer toelichting op voor Nederlanders onbekende woorden en begrippen in de aangehaalde teksten? Hij had een lijstje kunnen toevoegen met een korte verklaring. Het lijkt me dat bv. ook een leraar Nederlands in Nederland zèlf niet veel verder komt met de loutere vermelding van het woord 'cunucu' of 'mondi' zonder nadere uitleg; Vervoorn had hier al een begin kunnen maken. Vreemd vind ik ook de volgende opmerking van de schrijver op blz. 38: "In dat landschap treft men als markante punten aan de seú, de rooi en de koraal met kabrieten". Het laatste woord wordt voor de gemiddelde Nederlander misschien in de aangehaalde teksten enigszins duidelijk, maar 'rooi' al minder, men kan ernaar gissen. Maar 
hoe kan men de 'seú' begrijpen of als een markant punt zien in het landschap in de aangehaalde zin "Hij nam een schilderij op dat een seú voorstelde"? Een 'seú' is een oogstfeest. Dit zijn een paar voorbeelden waar Vervoorn door een kleine aanwijzing de mensen op weg had kunnen helpen. Bij de opsomming van een aantal muziekinstrumenten in teksten van auteurs relateert Vervoorn die aan het hoofdstuk 'Echo's uit Afrika' van R.A. Römer's Korsow (blz. 44). Hier was niet alleen een korte toelichting wenselijk maar ook een beschrijving van de herkomst van een aantal woorden zoals 'wiri', 'tambu', 'maraca' en 'cacho'. De betreffende passage valt weliswaar onder de paragraaf 'Bijdragen uit het Papiamento', maar in de verbinding met 'Echo's uit Afrika' kàn men de indruk krijgen dat het hier om Afrikaanse woorden en namen gaat. Voor 'wiri' en 'maraca' is dat definitief niet het geval. Het zijn oorspronkelijk Indiaanse woorden (zie artikelen en aantekeningen van C.H. de Goeje in W.I.G. 29, 1948 e.v. en G. Friederici Amerikanistisches Wörterbuch, 1960). Van 'tambu' en 'cacho' staat de herkomst van de woorden niet vast.

Ondanks de gesignaleerde tekortkomingen is Vervoorns eerste ontwerp voor de studie van het Antilliaans Nederlands een bijzonder nuttig begin van de exploratie van een vrijwel onbekend gebied. Moge hij mijn opmerkingen zien als een aanmoediging om door te gaan, daarbij voor ogen houdend dat een dergelijke studie een belangrijke functie kan vervullen tot het beter begrijpen van Antillianen en van de Antilliaanse cultuur. Voor veel Antillianen zèlf zal het als een enorme bevrijding werken en de reeds geconstateerde onzekerheid doen afnemen. Tenslotte ware te wensen dat de auteur in de toekomst niet alleen zijn materiaal put uit de geschreven bronnen, de literatuur, maar ook uit het gesproken Antilliaans Nederlands.

L.F. Triebels 